\title{
Decision Support System for Service Quality Using SMART and Fuzzy ServQual Methods
}

\author{
Sri Lestari ${ }^{1}$, Muhammad Reza Romahdoni ${ }^{2}$ \\ ${ }^{1,2}$ Informatics and Business Institute Darmajaya, Lampung, Indonesia \\ ${ }^{1}$ srilestariedarmajaya.ac.id, ${ }^{2 m}$.rezarhomadoni@gmail.com
}

\begin{abstract}
The Regional Technical Implementation Unit of the Tresna Werdha Social Home for the Elderly of Natar South Lampung does not yet have a systematic calculation, which can be a parameter of the quality level of each service. This study develops a system to solve the problem of the calculation gap between perceptions and expectations in determining the quality level of each service, namely the Decision Support System using the Simple Multi-Attribute Rating Technique Method (SMART) and Fuzzy Service Quality. The results showed that the SMART method obtained an accuracy rate of $85.71 \%, 75.00 \%$ Precision, $100 \%$ Recall, and $100 \%$ Specificity, while the Fuzzy Service Quality method obtained an accuracy rate of $71.43 \%, 66.67 \%$ Precision, $66.67 \%$ Recall, and $75.00 \%$ Specificity. So that the Simple Multi-Attribute Rating Technique Method (SMART Method) is superior, so it is more appropriate to solve the problem of decision-making on the level of service quality at the Regional Technical Implementation Unit of the Tresna Werdha Elderly Social Home, Natar South Lampung.
\end{abstract}

Keywords: Decision Support System, SMART, Fuzzy Service Quality

\section{INTRODUCTION}

The Regional Technical Implementation Unit of the Tresna Werdha Social Home for the Elderly of Natar South Lampung is a government agency providing community services, especially for the elderly. UPTD PSLU "TRESNA WERDHA" always strives to improve the quality of services including medical examinations and medicines, problem disclosure and data collection, supervision of eligibility, funeral arrangements for the eligibility of the deceased, and educational and skills services. However, the ongoing business processes in terms of service quality are considered to be less than optimal and not as expected. On the basis of this, it is necessary to develop a system that can assist in decision making to be able to address service quality gaps.

The decision support system is an interactive system, which helps decision making through the use of data and decision models to solve semi-structured and unstructured problems [1]. Some of the methods that are widely used in decision support systems are Analytical Analysis Process (AHP) [2], Simple Additive Weighting (SAW) [3], Technique For Others Reference by Similarity to Ideal Solution (TOPSIS) [4] and Simple Multi-Attribute Rating Technique Method (SMART Method) [5]. Also, it can apply fuzzy methods including Fuzzy Logic [6], Fuzzy Tsukamoto [7], Fuzzy Mamdani [8], Fuzzy Associative Memory (FAM) [9], and Fuzzy Service Quality [10][15].

This research uses the SMART method [11-13] and the Fuzzy Service Quality method [14-16], this is because both methods have been widely used in solving service quality problems through measuring the quality of existing services. The Regional Technical Implementation Unit of the Tresna Werdha Social Home for the Elderly of Natar South Lampung has been providing services to the elderly. These services include social services, physical services, psychosocial services, skills services, religious services, advisory services, and legal aid services. However, so far there has not been a systematic measurement that can be a parameter of the quality level of each service. While sometimes there are several complaints. Measuring the quality of service is very important as a basis for providing optimal services in accordance with the expectations of the elderly and related departments. Therefore this study develops a decision support system using the SMART method and the Fuzzy Service Quality method so that it can help the relevant parts to solve existing service problems so that the services provided by the Regional Technical Implementation Unit of the Tresna Werdha Social Home for the Elderly of Natar South Lampung is getting more optimal.

\section{METHOD}

This research was conducted at the Regional Technical Implementation Unit of the Tresna Werdha Elderly Social Home Natar South Lampung. The study collected data by means of an interview, questionnaire, observation, and study of literature. The method for 
decision making uses the SMART method and the Fuzzy Service Quality method.

\section{A. Data Collection}

Ukuran kertas yang digunakan dalam naskah adalah A4 $210 \mathrm{~mm}$ x $297 \mathrm{~mm}(8.27 "$ x $11.69 ")$. Batas margin halaman mengikuti ukuran:

1) Interview: Interviews were conducted with several employees at the Regional Technical Implementation Unit of the Tresna Werdha Elderly Social Home Natar South Lampung. This interview is to obtain information related to the type of service and priority level as a criterion weight parameter.

2) Questionnaire: his questionnaire is addressed to 40 elderly Regional Technical Implementation Unit of the Tresna Werdha Natar South Lampung Social Home to determine the perceptions and expectations of respondents (seniors) about the level of service quality. The questionnaire used in this case is closed, namely, a questionnaire that has provided the answer choices include Very Good, Good, Good Enough, Not Good, Very Bad so that the respondent just chooses and answers directly. The results of the report were then tested for validity and reliability using SPSS software to measure the validity of a questionnaire. A questionnaire is said to be valid if the questions on the questionnaire can reveal something that will be measured by the questionnaire.

3) Observation: Direct observation of the object being researched by understanding any information needed to continue research related to the quality of each service.

4) Study of literature:Collecting reference material in the form of theory from books, journals, and scientific papers as well as secondary data in the form of documents that support research results.

\section{B. Simple Multi-Attribute Rating Technique Method (SMART Method)}

SMART uses a linear additive model to predict the value of each alternative and its decision-making methods are flexible. This method provides a high understanding of the problem and can be accepted by decision-makers. Steps to complete the SMART method [3]:

1) Determining Criteria: In determining a decision support system, several criteria are needed in making decisions.
2) Determine the Weight: Determine the weight of the criteria for each criterion using intervals of 1-100 for each criterion with the most important priority.

3) Normalized Criteria Weights: Calculate the normalization of each criterion weight by comparing the criterion weight value with the total criterion weight. The calculation of the normalization of the criterion weights uses (1).

$$
\text { normalization }=\frac{w_{j}}{\sum w_{j}}
$$

Information :

$w_{j} \quad:$ weight of $\mathrm{j}$-criterion

$\sum w_{j} \quad$ : sum of the weights of all criteria

4) Set Value Criteria for Each Alternative: Provide the criteria parameter value for each criteria for each alternative. Each value is obtained from the conversion of the Likert scale from the perception and expectation questionnaire. There are 7 (seven) alternatives used in this study including social services, physical services, psychosocial services, skills services, religious services, assistance services, legal aid services.

5) Calculating Valuation /Utility: Determine the utility value by converting the criterion value on each criterion into the standard data criterion value. The calculation of the utility value uses (2).

$$
U_{i}(a i)=\frac{(\text { eout }-\mathcal{C} \text { min })}{(\text { (emax }-\mathcal{C} \text { min })}
$$

Information :

$U_{i}(a i):$ the utility value of the $\mathrm{j}$-criteria for the i-th alternative

Cmax : maximum criteria value

Cmin : minimum criterion value

Cout : the value of the alternative i criteria

6) Determine the Final Grade: Determine the final value of each criterion by transferring the value obtained from the normalized standard data criterion value with the criterion weight normalization value. The final value calculation uses (3).

Information :

$$
u_{i}(a i)=\sum_{j=1}^{m} \mathcal{W}_{j} * \mathcal{U}_{j}(a i)
$$

$U_{i}(a i):$ the total value for alternative i

$\mathcal{W}_{j} \quad:$ the value of the normalized $\mathrm{j}$-th criterion weight

$u_{j}(a i)$ : utility value for the $\mathrm{j}$-th criterion for the i-th alternative

7) Ranking: The results of the calculation of the final value are then sorted from the largest to the 
smallest, the alternative with the largest final value shows the best alternative.

\section{Fuzzy Service Quality}

Fuzzy servqual is a fuzzy set theory that is used as a means of presenting uncertainty and is a tool for modeling uncertainty related to disguises, uncertainties, and deficiencies regarding information related to certain elements and the problems faced. The steps for the Fuzzy Service Quality method [6]:

1) Determine the Fuzzy Set: Determination of the Fuzzy Set is done to determine the value of respondents' answers based on several criteria, namely Very Bad, Not Good, Good Enough, Good, and Very Good.

2) Fuzzification: At this stage, fuzzification calculations are carried out to obtain the lower limit (c), middle limit (a), and top limit (b) which are the values of the Triangular Fuzzy Number (TFN). Determination of the weight (score) in this research is used to determine the level of service quality which is categorized into 5, namely Very Bad, Not Good, Good Enough, Good, Very Good. In the Very Bad category with a score of 1,2,3,4; Not Good category with a score of 3,4,5,6; Good Enough category with a score of 5,6,7,8; Good category with a score of $7,8,9,10$; and Very Good category with a score of $9,10,11,12$. So that the fuzzy number format is obtained as in Table I. Fuzzification using (4), (5), (6).

3) Defuzzification: The next step is to calculate the defuzzification value of perceptions and expectations. This defuzzification is carried out to obtain a single, representative value. Defuzzification uses (5).

$$
\mu_{\mathrm{AnB}}=\left(\mu_{\mathrm{A}}[x]+\mu_{\mathrm{B}}[y]\right) / 2
$$

Information:

$\mu_{\mathrm{A} \cap \mathrm{B}}:$ the membership value of the slice of set $A$ with set $B$

$\mu_{\mathrm{A}}[x]$ : the membership value of an item $[\mathrm{x}]$ in a set A (middle limit fuzzification value)

$\mu_{B}[y] \quad$ : the membership value of an item $[y]$ in a set B (top limit fuzzification value)

\section{RESULTS AND DISCUSSION}

The decision support system to improve service quality in the Regional Technical Implementation Unit of the Tresna Werdha Elderly Social Home Natar South Lampung, uses two methods, namely the SMART method and the Fuzzy Service Quality method.

\section{A. SMART}

The SMART method consists of several stages in decision making, these stages are:

1) Determining Criteria: The criteria used in the research are C1 (Reliability), C2 (Responsiveness), C3 (Assurance), C4 (Empathy), C5 (Tangible) [10][17].

2) Determine the Weight of the Criteria: Determine the weights on each criteria using intervals of 1-100. The criteria with higher weight indicates the most important criteria, the total weight is 100 . The weights for each criteria can be seen in Table II.

3) Normalized Criteria Weights: Calculate the normalization of each criteria weight by comparing the criteria weight value with the total criteria weight. The normalization of the criteria weights can be seen in Table III.

$$
\begin{aligned}
& \text { Lower Limit (c) }=\frac{b_{i l} * n_{1}+b_{i l} * n_{2}+b_{i 2} * n_{3}+\ldots \ldots+b_{i(k-l)} * n_{k}}{n_{1}+n_{2}+n_{3}+\ldots \ldots .+n_{k}} \\
& \text { Middle Limit (a) }=\frac{b_{i l} * n_{1}+b_{i 2} * n_{2}+b_{i 3} * n_{3}+\ldots \ldots+b_{i k^{*} n_{k}}}{n_{1}+n_{2}+n_{3}+\ldots \ldots .+n_{k}} \\
& \text { Top Limit (b) }=\frac{b_{i l^{*} * n_{1}+b_{i 3} * n_{2}+\ldots \ldots+b_{i k} * n_{i(k-1)}+b_{i k} * n_{k}}}{n_{1}+n_{2}+n_{3}+\ldots \ldots .+n_{k}}
\end{aligned}
$$

Information:

$b_{i} \quad:$ average value of the fuzzy set at each level of importance

$\mathrm{n} \quad$ : number of respondents per level of importance

TABLE I

TRIANGULAR FUZZY NUMBER

\begin{tabular}{lccccc}
\hline \multirow{2}{*}{ Fuzzy Value } & \multicolumn{5}{c}{ Category } \\
\cline { 2 - 6 } & Very Bad & Not Good & Good Enough & Good & Very Good \\
\hline Lower Limit ( c ) & 1 & 3 & 5 & 7 & 9 \\
Middle Limit ( a ) & 2.5 & 4.5 & 6.5 & 8.5 & 10.5 \\
Top Limit ( b) & 4 & 6 & 8 & 10 & 12 \\
\hline
\end{tabular}


TABLE II

WEIGHT CRITERIA

\begin{tabular}{cc}
\hline Criteria & Weight \\
\hline $\mathrm{C} 1$ & 30 \\
$\mathrm{C} 2$ & 25 \\
$\mathrm{C} 3$ & 20 \\
$\mathrm{C} 4$ & 15 \\
$\mathrm{C} 5$ & 10 \\
Total & 100 \\
\hline
\end{tabular}

4) Set Value Criteria for Each Alternative: Assign a value to each criterion for each alternative. Each value is obtained from the conversion of the Likert scale from the perception and expectation questionnaire. There are 7 (seven) alternatives used in this study including social services, physical services, psychosocial services, skills services, religious services, assistance services, legal aid services. The value of each perception and expectation criterion can be seen in Table IV.

5) Calculating Valuation/Utility: Determine the utility value by converting the criterion value on each criterion into the standard data criterion value. The utility value can be seen in Table V.
TABLE III

NORMALIZATION OF CRITERIA WEIGHT

\begin{tabular}{ccc}
\hline Criteria & $\begin{array}{c}\text { Normalization=Value/total } \\
\text { weight }\end{array}$ & Normalization \\
\hline C1 & $30 / 100$ & 0.30 \\
C2 & $25 / 100$ & 0.25 \\
C3 & $20 / 100$ & 0.20 \\
C4 & $15 / 100$ & 0.15 \\
C5 & $10 / 100$ & 0.10 \\
Total & 100 & 100 \\
\hline
\end{tabular}

6) Determine the Final Grade: Determine the final value of each criterion by transferring the value obtained from the normalization of the standard data criteria value with the normalized criteria weight value. The final value of calculating perceptions and expectations using the SMART method can be seen in Table VI.

7) Ranking: The results of the calculation of the final value are then sorted from the largest to the smallest, the alternative with the largest final value shows the best alternative. The calculation ranking for each alternative can be seen in Table VII.

TABLE IV

CRITERIA VALUE OF PERCEPTION AND EXPECTATION

\begin{tabular}{ccccccccccc}
\hline \multicolumn{4}{c}{ Perception Criteria Value } & \multicolumn{4}{c}{ Expectation Criteria Value } \\
Alternative & C1 & C2 & C3 & C4 & C5 & C1 & C2 & C3 & C4 & C5 \\
\hline A1 & 64.5 & 68.5 & 64.5 & 64.5 & 65.5 & 83.5 & 87 & 83.5 & 83 & 85.5 \\
A2 & 65.5 & 65.5 & 63.5 & 63.5 & 62.5 & 83.5 & 85 & 83 & 83 & 81.5 \\
A3 & 77.5 & 64 & 63 & 61.5 & 65.5 & 82 & 82.5 & 82.5 & 81.5 & 85.5 \\
A4 & 64 & 62 & 61.5 & 62.5 & 66 & 83 & 81.5 & 81 & 82 & 85 \\
A5 & 66.5 & 67 & 63 & 62.5 & 63 & 86 & 85.5 & 80.5 & 82 & 82.5 \\
A6 & 61.5 & 65.5 & 55 & 64 & 62 & 81.5 & 84.5 & 74.5 & 83 & 80.5 \\
A7 & 64.5 & 63.5 & 60.5 & 61.5 & 58.5 & 83.5 & 82 & 80 & 81 & 77.5 \\
\hline
\end{tabular}

TABLE V

UTILITY PERCEPTION AND EXPECTATIONS

\begin{tabular}{|c|c|c|c|c|c|c|c|c|c|c|}
\hline \multirow{2}{*}{ Utility } & \multicolumn{5}{|c|}{ Perception } & \multicolumn{5}{|c|}{ Utility Expectation } \\
\hline & C1 & $\mathrm{C2}$ & $\mathrm{C3}$ & $\mathrm{C4}$ & C5 & C1 & $\mathrm{C2}$ & $\mathbf{C 3}$ & $\mathrm{C4}$ & C5 \\
\hline A1 & 0.188 & 1.000 & 1.000 & 1.000 & 1.000 & 0.444 & 1.000 & 1.000 & 1.000 & 1.000 \\
\hline $\mathrm{A} 2$ & 0.250 & 0.538 & 0.895 & 0.667 & 0.571 & 0.444 & 0.636 & 0.944 & 1.000 & 0.500 \\
\hline A3 & 1.000 & 0.308 & 0.842 & 0.000 & 1.000 & 0.111 & 0.182 & 0.889 & 0.250 & 1.000 \\
\hline A4 & 0.156 & 0.000 & 0.684 & 0.333 & 1.071 & 0.333 & 0.000 & 0.722 & 0.500 & 0.938 \\
\hline A5 & 0.313 & 0.769 & 0.842 & 0.333 & 0.643 & 1.000 & 0.727 & 0.667 & 0.500 & 0.625 \\
\hline A6 & 0.000 & 0.538 & 0.000 & 0.833 & 0.500 & 0.000 & 0.545 & 0.000 & 1.000 & 0.375 \\
\hline A7 & 0.188 & 0.231 & 0.085 & 0.000 & 0.000 & 0.444 & 0.091 & 0.611 & 0.000 & 0.000 \\
\hline
\end{tabular}


JUITA: Jurnal Informatika e-ISSN: 2579-8901; Vol. 9, No. 1, May 2021

TABLE VI

END OF PERCEPTIONS AND EXPECTATIONS

\begin{tabular}{ccccccccccccc}
\hline \multirow{2}{*}{ Utility } & \multicolumn{4}{c}{ Perception of Final Value } & \multicolumn{4}{c}{ Expectation Final Value Expectation } \\
\cline { 2 - 37 } & C1 & C2 & C3 & C4 & C5 & Final Value & C1 & C2 & C3 & C4 & C5 & Final Value \\
A1 & 0.06 & 0.25 & 0.20 & 0.15 & 0.10 & $75.63 \%$ & 0.13 & 0.25 & 0.20 & 0.15 & 0.10 & $83.33 \%$ \\
A2 & 0.08 & 0.13 & 0.18 & 0.10 & 0.06 & $54.57 \%$ & 0.13 & 0.16 & 0.19 & 0.15 & 0.05 & $68.13 \%$ \\
A3 & 0.30 & 0.08 & 0.17 & 0.00 & 0.10 & $64.53 \%$ & 0.03 & 0.05 & 0.18 & 0.04 & 0.10 & $39.41 \%$ \\
A4 & 0.05 & 0.00 & 0.14 & 0.05 & 0.11 & $34.09 \%$ & 0.10 & 0.00 & 0.14 & 0.08 & 0.09 & $41.32 \%$ \\
A5 & 0.09 & 0.19 & 0.17 & 0.05 & 0.06 & $56.88 \%$ & 0.30 & 0.18 & 0.13 & 0.08 & 0.06 & $75.27 \%$ \\
A6 & 0.00 & 0.13 & 0.00 & 0.13 & 0.05 & $30.96 \%$ & 0.00 & 0.14 & 0.00 & 0.15 & 0.04 & $32.39 \%$ \\
A7 & 0.06 & 0.06 & 0.02 & 0.00 & 0.00 & $13.10 \%$ & 0.13 & 0.02 & 0.12 & 0.00 & 0.00 & $27.83 \%$ \\
\hline
\end{tabular}

TABLE VII

RANKING OF PERCEPTIONS AND EXPECTATION

\begin{tabular}{cccccc}
\hline \multicolumn{2}{c}{ Perception Ranking } & \multicolumn{3}{c}{ Expectation Ranking } \\
\hline Ranking & Alternative & Value & Ranking & Alternative & Value \\
\hline 1 & A1 & $75.63 \%$ & 1 & A1 & $83.33 \%$ \\
2 & A3 & $64.53 \%$ & 2 & A5 & $75.27 \%$ \\
3 & A5 & $56.88 \%$ & 3 & A2 & $68.13 \%$ \\
4 & A2 & $54.57 \%$ & 4 & A4 & $41.32 \%$ \\
5 & A4 & $34.09 \%$ & 5 & A3 & $39.41 \%$ \\
6 & A6 & $30.96 \%$ & 6 & A6 & $32.39 \%$ \\
7 & A7 & $13.10 \%$ & 7 & A7 & $27.83 \%$ \\
\hline
\end{tabular}

From the results of the ranking above, it can be seen that the perception assessment gets the highest value of $75.63 \%$ for the A1 alternative and the lowest value is the A7 alternative $13.10 \%$, while the expectation assessment gets increased results with the highest value obtained for the A1 alternative with a value of $83.33 \%$ while the lowest value is the alternative A7 with a value of $27.83 \%$. So it can be concluded that the Simple Multi-Attribute Rating Technique Method (SMART Method) can be used to improve service quality.

\section{B. Fuzzy Service Quality}

Fuzzy Service Quality is a fuzzy set theory that is used as a means of presenting uncertainty and is a tool for modeling uncertainty related to obscurity, uncertainty, and shortcomings regarding information related to certain elements and the problems faced. Following are the results of calculations using Fuzzy Service Quality:
1) Determine the Fuzzy Set: Determination of the Fuzzy Set is done to determine the value of respondents' answers based on several criteria, namely Very Bad, Not Good, Good Enough, Good, and Very Good. The fuzzy set in this study can be seen in Fig. 1.

2) Fuzzification: At this stage, fuzzification calculations are carried out to obtain the lower limit (c), middle limit (a), and upper limit (b) which are the values of the Triangular Fuzzy Number (TFN). The Triangular Fuzzy Number value can be seen in Table 1, and the perception and expectation fuzzification value can be seen in Table VIII.

3) Defuzzification: The next step is to calculate the defuzzification value of perceptions and expectations. This defuzzification is carried out to obtain a single, representative value. The defuzzification value for the level of perception and expectation can be seen in Table IX. 


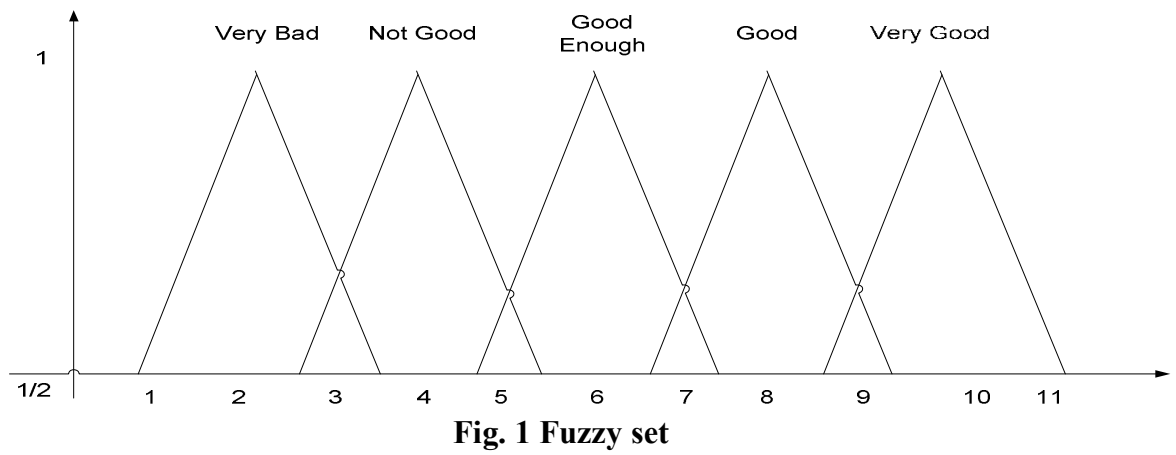

TABLE VIII

FUZZYFICATION VALUE OF PERCEPTION AND EXPECTATION

\begin{tabular}{|c|c|c|c|c|c|c|c|c|c|c|c|c|c|c|c|}
\hline \multicolumn{8}{|c|}{ TFN } & \multicolumn{8}{|c|}{ TFN } \\
\hline & & \multicolumn{3}{|c|}{ Perception } & \multicolumn{3}{|c|}{ Expectation } & \multirow[b]{2}{*}{$\begin{array}{c}\text { Alternativ } \\
\text { e }\end{array}$} & \multirow[b]{2}{*}{ Criteria } & \multicolumn{3}{|c|}{ Perception } & \multicolumn{3}{|c|}{ Expectation } \\
\hline Alternative & Criteria & c & $\mathbf{a}$ & $\mathbf{b}$ & c & $\mathbf{a}$ & $\mathbf{b}$ & & & c & $\mathbf{a}$ & $\mathbf{b}$ & c & $\mathbf{a}$ & $\mathbf{b}$ \\
\hline \multirow[t]{5}{*}{ A1 } & $\mathrm{C} 1$ & 5.45 & 6.95 & 8.45 & 7.35 & 8.85 & 10.35 & & $\mathrm{C} 4$ & 5.25 & 6.75 & 8.25 & 7.20 & 8.70 & 10.20 \\
\hline & $\mathrm{C} 2$ & 5.85 & 7.35 & 8.85 & 7.70 & 9.20 & 10.70 & & $\mathrm{C} 5$ & 5.60 & 7.10 & 8.60 & 7.50 & 9.00 & 10.50 \\
\hline & C3 & 5.45 & 6.95 & 8.45 & 7.35 & 8.85 & 10.35 & A5 & $\mathrm{C} 1$ & 5.65 & 7.15 & 8.65 & 7.60 & 9.10 & 10.60 \\
\hline & $\mathrm{C} 4$ & 5.45 & 6.95 & 8.45 & 7.30 & 8.80 & 10.30 & & $\mathrm{C} 2$ & 5.70 & 7.20 & 8.70 & 7.55 & 9.05 & 10.55 \\
\hline & $\mathrm{C} 5$ & 5.55 & 7.05 & 8.55 & 7.55 & 9.05 & 10.55 & & $\mathrm{C} 3$ & 6.18 & 7.86 & 9.55 & 7.05 & 8.55 & 10.05 \\
\hline \multirow[t]{5}{*}{$\mathrm{A} 2$} & $\mathrm{C} 1$ & 5.55 & 7.05 & 8.55 & 7.35 & 8.85 & 10.35 & & $\mathrm{C} 4$ & 5.25 & 6.75 & 8.25 & 7.20 & 8.70 & 10.20 \\
\hline & $\mathrm{C} 2$ & 5.55 & 7.05 & 8.55 & 7.50 & 9.00 & 10.50 & & $\mathrm{C} 5$ & 5.30 & 6.80 & 8.30 & 7.25 & 8.75 & 10.25 \\
\hline & C3 & 5.35 & 6.85 & 8.35 & 7.30 & 8.80 & 10.30 & A6 & $\mathrm{C} 1$ & 5.15 & 6.65 & 8.15 & 7.15 & 8.65 & 10.15 \\
\hline & C4 & 5.35 & 6.85 & 8.35 & 7.30 & 8.80 & 10.30 & & $\mathrm{C} 2$ & 5.55 & 7.05 & 8.55 & 7.45 & 8.95 & 10.45 \\
\hline & C5 & 5.25 & 6.75 & 8.25 & 7.15 & 8.65 & 10.15 & & C3 & 4.50 & 6.00 & 7.50 & 6.45 & 7.95 & 9.45 \\
\hline \multirow[t]{5}{*}{ A3 } & $\mathrm{C} 1$ & 6.60 & 8.33 & 10.05 & 7.20 & 8.70 & 10.20 & & $\mathrm{C} 4$ & 5.40 & 6.90 & 8.40 & 7.30 & 8.80 & 10.30 \\
\hline & $\mathrm{C} 2$ & 5.40 & 6.90 & 8.40 & 7.35 & 8.85 & 10.35 & & C5 & 5.20 & 6.70 & 8.20 & 7.05 & 8.55 & 10.05 \\
\hline & C3 & 5.30 & 6.80 & 8.30 & 7.25 & 8.75 & 10.25 & A7 & $\mathrm{C} 1$ & 5.45 & 6.95 & 8.45 & 7.35 & 8.85 & 10.35 \\
\hline & $\mathrm{C} 4$ & 5.15 & 6.65 & 8.15 & 7.15 & 8.65 & 10.15 & & $\mathrm{C} 2$ & 5.35 & 6.85 & 8.35 & 7.20 & 8.70 & 10.20 \\
\hline & $\mathrm{C} 5$ & 5.55 & 7.05 & 8.55 & 7.55 & 9.05 & 10.55 & & $\mathrm{C} 3$ & 5.05 & 6.55 & 8.05 & 7.00 & 8.50 & 10.00 \\
\hline \multirow[t]{3}{*}{ A4 } & $\mathrm{C} 1$ & 5.40 & 6.90 & 8.40 & 7.30 & 8.80 & 10.30 & & $\mathrm{C} 4$ & 5.15 & 6.65 & 8.15 & 7.10 & 8.60 & 10.10 \\
\hline & $\mathrm{C} 2$ & 5.20 & 6.70 & 8.20 & 7.15 & 8.65 & 10.15 & & $\mathrm{C} 5$ & 4.85 & 6.35 & 7.85 & 6.75 & 8.25 & 9.75 \\
\hline & $\mathrm{C} 3$ & 5.15 & 6.65 & 8.15 & 7.10 & 8.60 & 10.10 & & & & & & & & \\
\hline
\end{tabular}

TABLE IX

DEFUZZYFIKAS TABLE PER ALTERNATIVE PERCEPTIONS AND EXPECTATIONS

\begin{tabular}{cccc}
\hline \multicolumn{2}{c}{ Defuzzyfikas by Perception Alternative } & Defuzzyfikas Per EXPECTATIONS Alternative \\
\hline Alternative & Perception Defuzzyfication & Defuzzification of Expectations & Gap \\
\hline A1 & 7.80 & 9.70 & -1.90 \\
A2 & 7.66 & 9.57 & -1.91 \\
A3 & 7.92 & 9.55 & -1.63 \\
A4 & 7.57 & 9.50 & -1.93 \\
A5 & 7.92 & 9.58 & -1.66 \\
A6 & 7.41 & 9.33 & -1.92 \\
A7 & 7.42 & 9.33 & -1.91 \\
\hline
\end{tabular}

4) Service Quality Feasibility Test with SMART Method and Fuzzy Service Quality: The results that have been obtained will then be carried out a feasibility quality test for each service. Parameter determination is determined by looking for the mean value in the overall data. The parameters of the feasibility test for perceptions and expectations can be seen in Table $\mathrm{X}$ and the results of the feasibility test can be seen in Table XI and Table XII. 
From the measurement of the performance of the seven alternatives above using the SMART Method, three alternatives have a match between the perceived value and the expected value, including A1, A2, A5 with the TP (True Positive) match predicate, and three alternatives that have an improper compatibility value between the values. Perception and expectation values include A4, A6, A7 with the predicate TN (True Negative), while there is one alternative that has different compatibility between the perceived value and the expected value, namely the A3 alternative with the FP predicate (False Positive). Also, the results of the Fuzzy Service Quality method, two alternatives have a Decent match between the perceived value and the expected value, including A1 and A5 with the TP (True Positive) match predicate, and three alternatives that have an Improper compatibility value between the perceived and The expected values include A4, A6, A7 with the predicate TN (True Negative), while two alternatives have a different match between the perceived value and the expected value, namely the alternative A2 with the predicate FP (False Positive) and A3 with the predicate FN (False Negative). Thus, it can be concluded that the SMART Method is superior in identifying the match between the perceived value and the expected value of each alternative.

5) Measurement of Performance SMART Method and Fuzzy Service Quality: Performance measurement is carried out to determine the Accuracy, Precision, Recall, and Specificity of each service using the SMART Method and Fuzzy Service Quality. Performance measurement is obtained using the confidence matrix formula. The results of performance measurement can be seen in Table XIII.

TABLE X

FEASIBILITY PARAMETERS

\begin{tabular}{cccccccc}
\hline \multicolumn{3}{c}{ The SMART Method Eligibility Parameters } & \multicolumn{2}{c}{ Fuzzy Service Quality Feasibility Parameters } \\
\hline \multicolumn{2}{c}{ Perception } & \multicolumn{2}{c}{ Expectation } & \multicolumn{2}{c}{ Perception } & \multicolumn{2}{c}{ Expectations } \\
\hline Parameter & Value & Parameter & Value & Parameter & Value & Parameter & Value \\
\hline $47.12 \%-100 \%$ & Worth it & $52.54 \%-100 \%$ & Worth it & $7.68-10$ & Worth it & $9.52-10$ & Worth it \\
$0 \%-47.11 \%$ & Not worth it & $0 \%-52.53 \%$ & Not worth it & $0-7.67$ & Not worth it & $0-9.51$ & Not worth it \\
\hline
\end{tabular}

TABLE XI

RESULTS OF THE SMART METHOD FEASIBILITY TEST

\begin{tabular}{cccccc}
\hline Alternative & Value Perception & $\begin{array}{c}\text { Value } \\
\text { Expectations }\end{array}$ & $\begin{array}{c}\text { Worthiness } \\
\text { Perception }\end{array}$ & $\begin{array}{c}\text { Worthiness } \\
\text { Expectations }\end{array}$ & Compatibility \\
\hline $\mathbf{A 1}$ & $75.63 \%$ & $83.33 \%$ & Worth it & Worth it & TP \\
A2 & $54.57 \%$ & $68.13 \%$ & Worth it & Worth it & TP \\
A3 & $64.53 \%$ & $39.41 \%$ & Worth it & Not worth it & FP \\
A4 & $34.09 \%$ & $41.32 \%$ & Not worth it & Not worth it & TN \\
A5 & $56.88 \%$ & $75.27 \%$ & Worth it & Worth it & TP \\
A6 & $30.96 \%$ & $32.39 \%$ & Not worth it & Not worth it & TN \\
A7 & $13.10 \%$ & $27.83 \%$ & Not worth it & Not worth it & TN \\
\hline
\end{tabular}

TABLE XII

FUZZY SERVICE QUALITY FEASIBILITY TEST RESULTS

\begin{tabular}{cccccc}
\hline Alternative & Value Perception & $\begin{array}{c}\text { Value } \\
\text { Expectations }\end{array}$ & $\begin{array}{c}\text { Worthiness } \\
\text { Perception }\end{array}$ & $\begin{array}{c}\text { Worthiness } \\
\text { Expectations }\end{array}$ & Compatibility \\
\hline A1 & 7.80 & 9.70 & Worth it & Worth it & TP \\
A2 & 7.66 & 9.57 & Not worth it & Worth it & FP \\
A3 & 7.92 & 9.55 & Worth it & Not worth it & FN \\
A4 & 7.57 & 9.50 & Not worth it & Not worth it & TN \\
A5 & 7.92 & 9.58 & Worth it & Worth it & TP \\
A6 & 7.41 & 9.33 & Not worth it & Not worth it & TN \\
A7 & 7.42 & 9.33 & Not worth it & Not worth it & TN \\
\hline
\end{tabular}


TABLE XIII

PERFORMANCE SMART METHOD AND FUZZY SERVICE QUALITY

\begin{tabular}{ccc}
\hline Performance & $\begin{array}{c}\text { Smart } \\
\text { Method }\end{array}$ & $\begin{array}{c}\text { Fuzzy Service } \\
\text { Quality }\end{array}$ \\
\hline Accuracy & $85.71 \%$ & $71.43 \%$ \\
Precission & $75.00 \%$ & $66.67 \%$ \\
Recall & $100 \%$ & $66.67 \%$ \\
Specificity & $100 \%$ & $75.00 \%$ \\
\hline
\end{tabular}

Based on the results of the research, after measuring the two methods, namely the SMART method and the Fuzzy Service Quality method, it shows that the SMART method is superior to Fuzzy Service Quality which is indicated by a higher value in both accuracy, precision, recall, and Specificity. With the result that for the case of decision making in an effort to improve the quality of services at the Regional Technical Implementation Unit of the Tresna Werdha Elderly Social Home Natar South Lampung, it is more appropriate to adopt the results of the SMART Method.

\section{CONCLUSION}

The results of this research can be concluded that the SMART method is superior with an accuracy value of $14.28 \%$ higher than Fuzzy Service Quality. This shows that the measurement results from the SMART method can be used as a reference for decision making in improving service quality at the Regional Technical Implementation Unit of the Tresna Werdha Elderly Social Home Natar South Lampung. The level of service quality at the Regional Technical Implementation Unit of the Tresna Werdha Elderly Social Home Natar South Lampung is still low due to the current condition of service quality and the expected service quality is still an average gap of -1.84 . Hence the Regional Technical Implementation Unit of the Tresna Werdha Elderly Social Home Natar South Lampung to improve service quality by referring to the measurement results of this study. As for the next research, to add the variables used in measuring service quality.

\section{REFERENCES}

[1] I. M. A. Santosa, "Perancangan Sistem Pendukung Keputusan Pemilihan Sekolah Menggunakan Metode SMART," in Konferensi Nasional Sistem \& Informatika 2017, 2017, pp. 446-451.

[2] R. A. Suherdi, T. Rohmat, Yanuardi, and A. A. Permana, "Penerapan Metode AHP Dalam Sistem Pendukung Keputusan Kenaikan Pangkat Pegawai Di Bandan Kepegawaian dan Pengembangan Sumber Daya Manusia Kota Rangerang," in Prosiding SINTAK, 2018, pp. 522-
528.

[3] F. Mochammad, F. Syarief, and S. Suwandana, "Analisis dan Perancangan Decision Support System Menentukan Angkat Kredit Dengan Metode SAW (Simple Additive Weighting) Pada Leasing OTO Finance Batan," J. Sist. Inf. dan Manaj., vol. 6, no. 1, 2018.

[4] J. Siregar, "Sistem Pendukung Keputisan Pemberian KPR (Kredit Pemilikan Rumah) Untuk Nasabah Pemohon Menggunakan Metode TOPSIS (Studi Kasus PT. Bank Centra Asia.TBK," J. Pelita Inform., vol. 6, no. 1, pp. 129-136, 2017.

[5] A. Rahmatulloh and R. Rianto, "Sistem Pendukung Keputusan Layanan Verifikator Pengadaan dengan Metode Simple Multi Attribute Rating Technique (SMART)," JUITA, vol. VI, no. 2, pp. 99-111, 2018.

[6] J. Prayudha, A. Pranata, and A. Al Hafiz, "Implementasi Metode Fuzzy Logic Untuk Sistem Pengukuran Kualitas Udara di Kota Medan Berbasis Internet of Things (IOT)," J. Teknol. dan Sist. Inf., vol. IV, no. 2, pp. 141-148, 2018.

[7] A. T. P. Abza, "Identifikasi Tingkat Kepuasan Pelayanan Konsumen Industri Televisi Berlangganan Dengan Logika Fuzzy Metode Tsukamoto," J. Intra-Tech, vol. 2, no. 1, pp. 16-30, 2018.

[8] A. Ikhwan, M. Badri, M. Andriani, and N. Saragih, "Analisis Tingkat Kepuasan Pelanggan Menggunakan Fuzzy Mamdani ( Studi Kasus : Busrain Bakery )," Sains dan Komput., vol. 18, no. 2, pp. 147-153, 2019.

[9] M. Dahria, S. N. Arief, I. Santoso, and R. Kustini, "Sistem Pendukung Keputusan Menentukan Tingkat Kepuasan Customer Terhadap Pelayanan Jasa Kebersihan Di PT . Sas Menggunakan Metode Fuzzy Asosiative Memory," J. Teknol. Sist. Inf. dan Sist. Komput. TGD, vol. 3, no. 1, pp. 1-10, 2020.

[10] D. Suranti and Y. Yupianti, "Implementasi Fuzzy Servqual dalam Evaluasi Kualitas Pelayanan Penyuluh Pertanian," J. Teknol. dan Sist. Komput., vol. 7, no. 4, pp. 147-153, 2019.

[11] M. Guntur and R. Yanto, "Penerapan Metode SMART untuk Seleksi Kelayakan Penerima Bantuan Pengembangan Usaha Pangan Masyarakat," Telematika, vol. 12, no. 2, pp. 149-159, 2019.

[12] S. R. Andani and A. S. P. Keputusan, "Penerapan Metode SMART Dalam Pengambilan Keputusan Penerima Beasiswa Yayasan AMIK Tunas Bangsa," J. Sist. dan Teknol. Inf., vol. 7, no. 3, pp. 166-170, 2019.

[13] T. Magrisa, K. Diah, and K. Wardhani, "Implementasi Metode SMART Pada Sistem Pendukung Keputusan Pemilihan Kegiatan Ekstrakurikuler Untuk Siswa SMA," Inform. Mulawarman J. Ilm. Ilmu Komput., vol. 13, no. $1,2018$.

[14] N. F. Kartika, "Implementasi Fuzzy - Service Quality Terhadap Tingkat Kepuasan Layanan," J. Ilm. SISFOTENIKAJ, vol. 7, no. 1, pp. 38-49, 2017.

[15] Frieyadie and D. Alramuri, "Implementasi Metode Fuzzy 
Servqual Untuk Menilai Pelayanan Customer Service Terhadap Kepuasan Pelanggan di PT. Telkom," $J$. Techno Nusa Mandiri, vol. 14, no. 2, pp. 111-115, 2018.

[16] E. Sutinah and O. R. Simamora, "Metode Fuzzy Servqual Dalam Mengukur Kepuasan Pasien Terhadap Kualitas Layanan BPJS Kesehatan,” J. Inform., vol. 5, no. 1, pp.
90-101, 2018.

[17] N. F. Kartika and Suprayogi, "Implementasi Fuzzy Service Quality Terhadap Tingkat Kepuasan Layanan Mahasiswa," J. Ilm. SISFOTENIKA, vol. 7, no. 1, pp. 3849, 2017. 
JUITA: Jurnal Informatika e-ISSN: 2579-8901; Vol. 9, No. 1, May 2021 